Reunião Anual da Food Chemistry Division - EuChemS

\section{EuChems}

\section{European Chemical Society}

- Division of Food Chemistry

Devido à pandemia de COVID-19, a reunião anual da Food Chemistry Division da European Chemical Society (FCD-EuChemS) teve lugar online, no dia 20 de novembro de 2020, via plataforma Zoom. Estiveram presentes 26 delegados e um antigo presidente em representação de Sociedades de Química de 20 países diferentes, entre os quais a Sociedade Portuguesa de Química.

No âmbito desta reunião anual tiveram lugar as eleições para diferentes cargos da Divisão. A nova direção para o mandato 2021-2023, estabelecida após votação individual, é constituída por Joana Amaral (presidente), da Sociedade Portuguesa de Química, Cristina Todasca (secretária), da Sociedade Romena de Química, e Michael Murkovic (tesoureiro), da Sociedade Austríaca de Química. Nesta

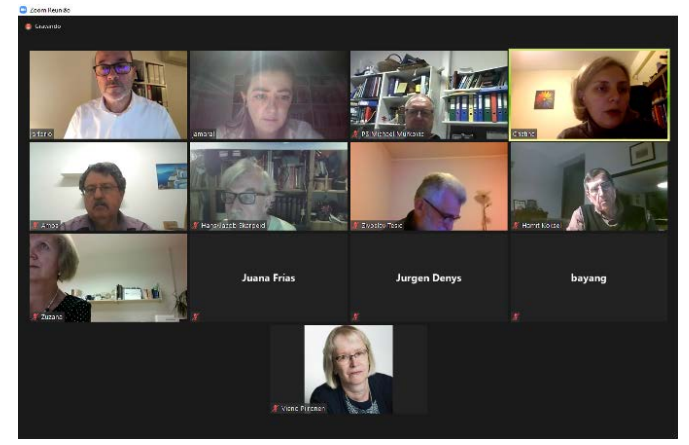

Imagem da reunião de trabalho.

reunião foi ainda discutido o adiamento do congresso EuroFoodChem, o qual estava previsto realizar-se em Belgrado, Sérvia, em setembro de 2021 e que, devido às restrições impostas pela pandemia, terá lugar no mesmo local em 2023. Foi ainda discutida a criação de um prémio atribuído pela FCD a um jovem investigador europeu a desenvolver trabalhos na área da Química Alimentar ou afins, prémio este que está previsto ser implementado brevemente após a criação do respetivo regulamento.

Joana Amaral

Representante da SPQ na FCD-EuChemS

jamaral@ipb.pt

\title{
Prémio EuChemS Service de 2020 Atribuído a Antonio Laganà e Jan Mehlich
}

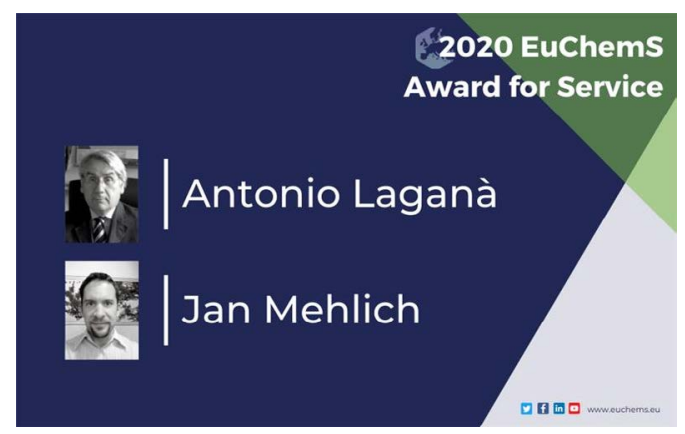

O prémio EuChems Service de 2020 foi concedido ao Professor Antonio Laganà e ao Dr. Jan Mehlich como reconhecimento do seu excelente compromisso e do seu trabalho árduo na promoção da Química na Europa, em linha com as atividades e objetivos da EuChems.

O Professor Laganà (Universidade de Perugia, Itália) tem contribuído para a comunidade Química na Europa e não só, servindo no conselho editorial de várias revistas e organizando várias conferências científicas, além das suas realizações científicas e demais serviços para a comunidade.

O Dr. Jan Mehlich, especialista em ética aplicada à ciência e tecnologia, desenvolveu o curso online gratuito "Química Boa - Implicações Metodológicas, Éticas e Sociais" (plataforma Moodle da EuChemS: elearning-euchems.eu). Cerca de 400 alunos já se inscreveram, contribuindo assim para a divulgação de uma conduta ética na Química.

0 prémio será entregue aos vencedores durante o $8 .^{\circ}$ Congresso de Química EuChems que decorrerá em Lisboa em 2022. A lista de todos os vencedores deste prémio pode ser consultada em: euchems.eu/awards/award-for-service.

$>$

Bruno Machado

brunofm@fe.up.pt 